\title{
Historical and contemporary forest ecosystem changes in the Beskid Mountains (southern Poland) between 1848 and 2014
}

\author{
Michal Sobala, \\ Oimahmad Rahmonov, \\ Urszula Myga-Piatek
}

\begin{abstract}
Landscape changes in the Carpathians are related to centuries of human activity, which can be regarded as the key component of global change. Changes in mountainous regions are mainly caused by agriculture, urbanization, forest cutting for production and land abandonment. This paper aimed to assess the impact of natural and historical-cultural factors on forest ecosystem transformations occurred in the period 1848-2014 in two small areas (about $45 \mathrm{~km}^{2}$ ) on the Beskid Mountains (southern Poland). The comparison of historical and current maps, along with the application of GIS and field verification, allowed a full interpretation of changes in land use in the studied areas. A decrease of $58.0 \%$ in non-forest areas was observed in the considered period, while the forested area grew systematically by $\mathbf{2 8 . 3 \%}$ and the forest-field boundary lowered in altitude. Current forest ecosystems are distributed as a mosaic and mainly consist of Dentario glandulosae-Fagetum, Luzulo nemorosae-Fagetum, Abieti-Piceetum montanum, with logged sites taking up large areas. Forest ecosystems include valuable semi-natural meadows such as Gladiolo-Agrostietum, Hieracio-Nardetum, Arrhenatheretum medioeuropaeum, Cirsietum rivularis or Juncetum effusi, whose extension is reducing and fragmentation increasing due to the recolonization of forest tree species after abandonment. We concluded that trends in land use in the Carpathians were mainly determined by non-environmental factors related to the development of farmingpasturing and forest management. The applied approach could be extended to other regions in the Carpathians which were subject to analogous historicalcultural influences. Moreover, our results allow for a comparison with other regions which are subject to similar impacts of natural processes, but to different impact of historical and cultural processes.
\end{abstract}

Keywords: Landscape Research, Forest Transformation, Land Use Changes, Historical Maps, Poland, Beskid Mountains, Carpathians

\section{Introduction}

Landscape is subject to increasing anthropogenic transformation in land use or land cover, which can be interpreted both locally and globally (Antrop 2005, Plit 2014). Analysis and evaluation of the rate of these changes are feasible when reliable carto graphic resources recording land use and types of land cover through time are available. Beside the educational value, the in terpretation of these resources is also important from the economic point of view, as it makes possible the optimization of contemporary economic processes (Plien- inger et al. 2016). Analysis of changes in land use over time also enables to assess the impact of natural factors - both positive (fertile soils, small height differences, mild climate, etc.) and negative (flooding, mass-movements, volcanic eruptions, pest gradation, natural fires, etc.) on the landscape.

Landscape diversification has increased in the past decades, often resulting in disturbances to the functioning of ecosystems (Goldewijk 2001, Hansen et al. 2010). Typological diversification of landscapes has been occurring over time because of hu- $\square$ University Silesia in Katowice, Faculty of Earth Sciences, Bedzinska 60, 41-200 Sosnowiec (Poland)

@ Oimahmad Rahmonov (oimahmad.rahmonov@us.edu.pl)

Received: Mar 02, 2017 - Accepted: Sep 08, 2017

Citation: Sobala M, Rahmonov O, Myga-Piatek U (2017). Historical and contemporary forest ecosystem changes in the Beskid Mountains (southern Poland) between 1848 and 2014.

iForest 10: 939-947. - doi: 10.3832/ifor2418-010 [online 2017-12-19]

Communicated by: Susanna Nocentini man economic activities through centuries, determining the development of specific anthropogenic ecological systems within various landscape zones (Farina 2000, Vold \& Buffett 2008, Myga-Piatek 2012, Munteanu et al. 2014, Ellis 2015, Pienkowski 2015). Such activities include urbanization, intensification of agriculture, forest cutting for production and/or land abandonment (Plieninger et al. 2016), whose impact varies regionally depending on local socio-economic and natural conditions (Pinto-Correia \& Kristensen 2013).

The main types of landscape change over Europe and their driving factors have been widely discussed in a recent review (Plieninger et al. 2016). Similar analyses have been carried out in the Carparthians (Griffiths et al. 2013, Munteanu et al. 2014), and in areas adjacent to the Beskid Mountains in Poland (Boltiziar et al. 2016), mainly focused on changes in forest areas and the farming use of land. Changes in the forest cover over the past 180 years have been examined in western and northern Carpathians (Kozak 2003, 2010, Kozak et al. 2007).

Carpathian mountain range covers more than $190,000 \mathrm{~km}^{2}$ throughout eastern Eu- 


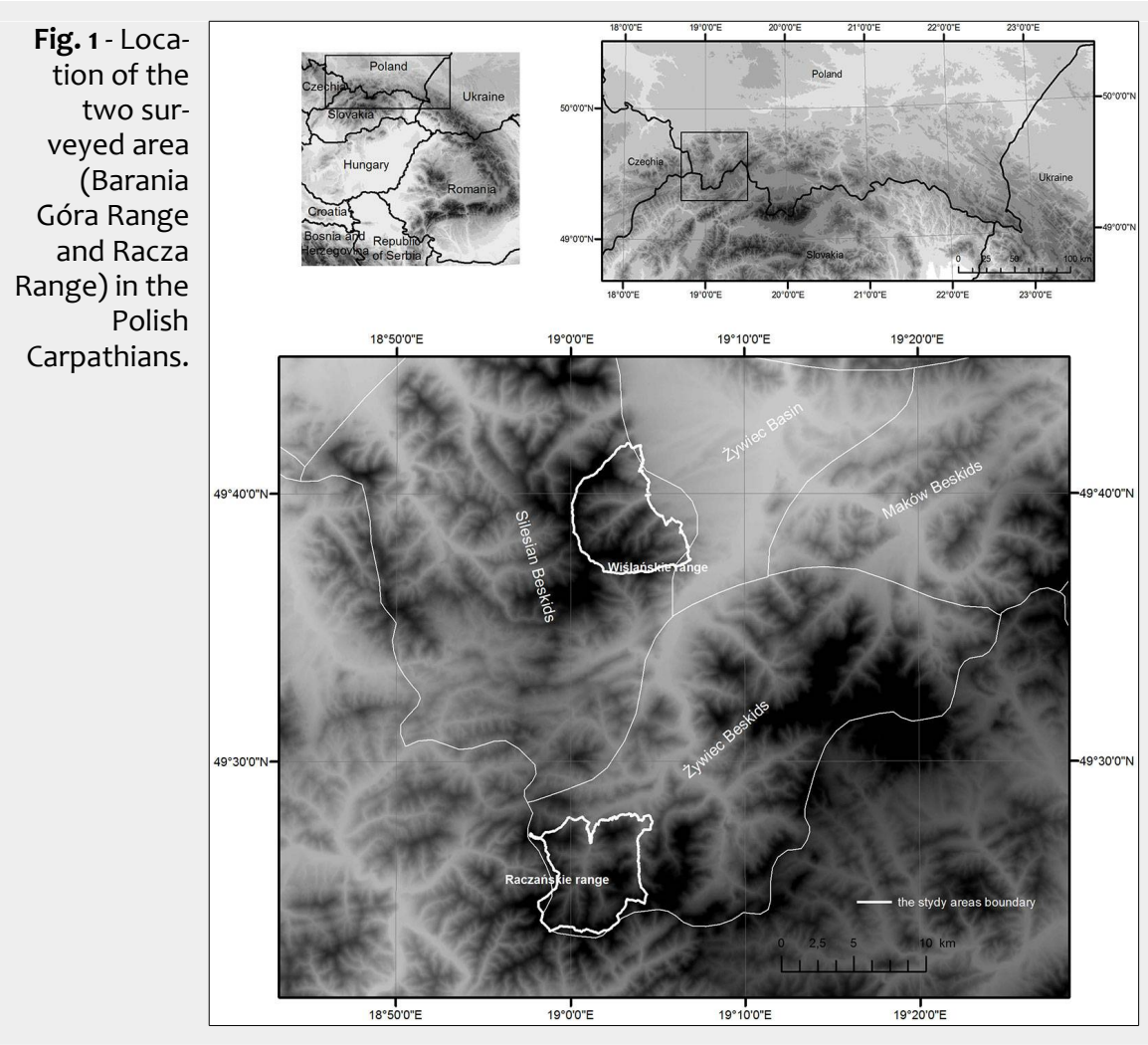

rope, extending for $1300 \mathrm{~km}$ in length and $120-350 \mathrm{~km}$ in width, and includes a unique combination of ecosystems. The Carpathians run through as many as 7 countries: Slovakia (about $71 \%$ of its area), Romania (ca. 47\%), Czechia (ca. 8\%), Hungary (ca. 8\%), Poland (over 6\%), Ukraine, Austria and Serbia. As a consequence, different models of land management, determined both historically and culturally, have appeared and still exist in different parts of the Carpathians (Munteanu et al. 2014), resulting in regional differences in changes in ecosystems and landscapes.

Changes in specific landscape elements (forests, abandoned land, meadows, hydrographic networks, cultural elements) have been analysed throughout the Carpathian range with different degrees of detail (Kaim 2009, Ostafin 2009, Kozak 2010). However, most studies were large-scales investigations based on either cartographic resources or satellite- and aerial imagery aimed at quantifying changes in forest cover (Kozak et al. 2007, Munteanu et al. 2014). Contrastingly, few studies have focused on changes in species composition of forests in the Silesian and Zywiec Beskid Mountains, which are part of the Polish Carpathians.

The aim of this paper was to determine the impact of natural and historical-cultural factors on forest ecosystem transformations in the Silesian and Zywiec Beskid Mountains over the period 1848-2014. An accurate assessment of landscape changes was carried out in two small mountainous areas $\left(<100 \mathrm{~km}^{2}\right)$ which had been exploited by man for centuries. A detailed verification in the field of the results obtained from cartographic analyses allowed to recognize the transformation of fir-beech phy-

Tab. 1 - Cartographic materials used for the analyses.

\begin{tabular}{|c|c|c|c|}
\hline Map type & Map sheets & Year & Scale \\
\hline Austrian cadastral maps & $\begin{array}{l}\text { Lipowa, Ostre, Radziechowy, } \\
\text { Rycerka Górna }\end{array}$ & 1848 & $1: 2,880$ \\
\hline Spezialkarte der & Saysbush & 1879 & $1: 75,000$ \\
\hline $\begin{array}{l}\text { Österreichisch-Ungarischen } \\
\text { Monarchie }\end{array}$ & Ujsoly-Stara Bistrica & 1885 & $1: 75,000$ \\
\hline WIG military map & Zywiec, Ujsoly & 1933 & $1: 100,000$ \\
\hline \multirow[t]{2}{*}{ Military topographic map } & Szczyrk, Wegierska Górka & 1960 & $1: 25,000$ \\
\hline & $\begin{array}{l}\text { Nova Bistrica, Oscadnica, Rycerka } \\
\text { Dolna, Zborov nad Bistricou }\end{array}$ & 1975 & \\
\hline Topographic map of Poland & $\begin{array}{l}\text { Barania Góra, Lipowa, Mlada Hora, } \\
\text { Przegibek, Szczyrk Malinów, Tatarki, } \\
\text { Wegierska Górka, Wielka Racza }\end{array}$ & 1979 & $1: 10,000$ \\
\hline Orthophotomap & - & 2009 & $\begin{array}{l}\text { field pixel size } \\
\text { of } 0.25 \mathrm{~m}\end{array}$ \\
\hline
\end{tabular}

tocenoses and the succession in managed spruce forests in the light of natural and anthropogenic factors.

\section{Materials and methods}

\section{Description of the study area}

The Beskid range (Western Carpathians) stretches for about $600 \mathrm{~km}$ from the Bečva River in the west to the Cheremosh River in the east, and reaches a width of about 50$70 \mathrm{~km}$. We selected two research areas (the Barania Góra Range and Racza Range, each covering about $45 \mathrm{~km}^{2}$ ) situated in the Western Beskids ( $49^{\circ} 32^{\prime} 45^{\prime \prime} \mathrm{N}, 1^{\circ} 26^{\prime} 5^{\prime \prime} \mathrm{E}$ - Fig. 1), both characterized by mediumand low mountain relief with steep slopes (mean elevation $>800 \mathrm{~m}$ a.s.l.). The basement is made from formations of the Godula Nappe and the Magura Nappe of the Carpathian Flysch Belt. The areas span over three vertical climatic zones, namely, moderate warm (with mean temperature $>6$ $\left.{ }^{\circ} \mathrm{C}\right)$, moderate cool $\left(4-6{ }^{\circ} \mathrm{C}\right)$ and cool $(<4$ $\left.{ }^{\circ} \mathrm{C}\right)$. Precipitation on the highest ridges (Skrzyczne or Wielka Racza) reaches 1300 mm year ${ }^{-1}$.

The natural conditions of the area are suitable to forests and meadows/grasslands, whereas current land use reflects the socio-political and economic conditions in the late $19^{\text {th }}$ century, when the Beskid region was heavily populated and large areas were deforested for agricultural use, despite unfavourable topographic-, soil- and climatic conditions (Sobala 2012a). This has generated the current traditional landscape typical of the Beskid region, with buildings situated in the valley bottom on lower river terraces with accompanying woods and shrubs, and cropfields perpendicular to the valley bottom divided by clearly marked baulks, which reach up to the edge of the forest on mountain ridges. Numerous clearings with farmsteads are located in flat areas of the forest, and mountain ridges includes pasture grounds which recently decreased in area due to the abandonment of breeding farm management.

\section{Cartographic analysis}

For the analysis of changes in landscape over time, only maps based on direct field mapping were selected in this study. We decided to select map series with similar scales and objectives; however, we encountered serious difficulties to match such criteria. Therefore, only six of the seven maps acquired were used in this study, as reported in Tab. 1.

All the historical maps were georeferenced in two steps, which consisted in: (i) calculating the transformation matrix; (ii) carrying out proper geometric transformation and interpolation resampling of a distorted image to a new raster of regular size (i.e., the so-called "rubbersheeting"). Such two-step process allowed a higher georeferencing accuracy, which ensures the quality of results obtained and increases the 
confidence in the conclusions. In each case, georeferencing was specifically adjusted to the quality and type of data, so as to achieve the best possible results for each series.

Austrian cadastral maps were overlaid onto a grid with a size corresponding to the map frame size using affine transformation and the coordinates of the frame corners. Rectification was then carried out and its precision verified by estimating the root-mean-square error (RMSE), which was $<4.91 \mathrm{~m}$ for each map sheet.

The Spezialkarte der Österreichisch-Ungarischen Monarchie was georeferenced only by means of control points of the reference layer using the affine transformation. This kind of georeferencing of a single map sheet gives better results than that based on fitting the corners in the millimetermesh grid (Affek 2013).

The military maps were georeferenced by overlaying the corner points of the raster image onto the grid with a size corresponding to the map frame size using affine transformation. Rectification was then carried out and the image was adjusted to the reference layer using control points.

For all maps, historical local reference system was transformed into the contemporary global system. This step involved the application of a simplified Helmert transformation with three parameters $(\mathrm{dx}, \mathrm{dy}$, $\mathrm{dz}$ ) of the shift in the coordinate system origin using the inverse Molodensky formulas (Sobala 2012a).

The processed cartographic materials underwent screen digitization using the snapping method. Errors are usually generated during this operation, e.g., duplicating arcs, floating- or short lines, overlapping lines, overshoots and undershoots, unclosedand weird polygons (Maras et al. 2010). A topology construction tool was used to detect and eliminate these errors.

Screen digitization was combined with the creation of a database of land-use and land-cover forms. By aggregating the data included in each series of maps, land-cover maps were developed where forest and non-forest areas were clearly distinguishable. In both cases, the road network and the hydrographic network were attached to the adjoining polygons, as the boundaries ran along roads and watercourses.

As a result of the procedures described above, vector maps were created which allowed spatial analyses to be carried out. The V LATE add-on of the package ArcGIS ${ }^{\circledR}$ ver. 10.2.2 was used, which allowed to calculate landscape metrics describing land cover and the forest-field boundary in each time section. Indicators of changes in forest and non-forest cover in each time section were calculated by the following parameters:

- Changes in Forest Area $\left(C F=F A_{\mathrm{t}+1}-F A_{\mathrm{t}}\right)$;

- Changes in Non-forest Area $\left(C N=N A_{\mathrm{t}+1}-\right.$ $\left.N A_{\mathrm{t}}\right)$;

- Changes in Forest Area in relation to Total
Tab. 2 - Changes in land cover between 1848 and 2014. (FA): Forest Area; (FPL): Forest Percentage of Landscape; $(N F P)$ : Number of Forest Patches; $(M F A)$ : Maximal Forest Patches Area; $(N A)$ : Non-forest Area; $(N P L)$ : Non-forest Percentage of Landscape; $(N N P)$ : Number of Non-Forest Patches; $(M N A)$ : Maximal Non-Forest Patches Area.

\begin{tabular}{lccccccccc}
\hline Range & $\begin{array}{c}\text { Time } \\
\text { section }\end{array}$ & $\begin{array}{c}\boldsymbol{F A} \\
\text { (ha) }\end{array}$ & $\begin{array}{c}\boldsymbol{F P L} \\
\text { (\%) }\end{array}$ & $\boldsymbol{N F P}$ & $\begin{array}{c}\boldsymbol{M} \boldsymbol{M} \boldsymbol{A} \\
\text { (ha) }\end{array}$ & $\begin{array}{c}\boldsymbol{N} \boldsymbol{A} \\
\text { (\%) }\end{array}$ & $\begin{array}{c}\boldsymbol{N} P \boldsymbol{c}(\%) \\
\text { (\%) }\end{array}$ & NNP & $\begin{array}{c}\boldsymbol{M} \boldsymbol{M} \boldsymbol{A} \\
\text { (ha) }\end{array}$ \\
\hline Barania & 1848 & 3699.1 & 82.1 & 9 & 3693.9 & 807.2 & 17.9 & 142 & 165.7 \\
Góra & 1879 & 3707.5 & 82.3 & 2 & 3706.5 & 798.8 & 17.7 & 95 & 174.0 \\
& 1933 & 3840.8 & 85.2 & 1 & 3848.1 & 665.5 & 14.8 & 83 & 84.6 \\
& 1960 & 4145.3 & 92.0 & 12 & 4116.3 & 361.0 & 8.0 & 100 & 58.6 \\
& 1979 & 4213.9 & 93.5 & 14 & 4217.8 & 292.4 & 6.5 & 151 & 38.0 \\
& 2014 & 4230.2 & 93.9 & 18 & 4226.0 & 276.1 & 6.1 & 106 & 25.4 \\
\hline Racza & 1848 & 3137.8 & 68.8 & 17 & 2994.7 & 1423.0 & 31.2 & 89 & 462.3 \\
& 1885 & 3164.0 & 69.4 & 14 & 2819.8 & 1396.8 & 30.6 & 49 & 435.8 \\
& 1933 & 3262.5 & 71.5 & 15 & 2627.8 & 1298.3 & 28.5 & 33 & 454.9 \\
& 1975 & 3592.2 & 78.8 & 48 & 3530.0 & 968.6 & 21.2 & 89 & 394.5 \\
& 1979 & 3619.4 & 79.4 & 79 & 3292.1 & 941.4 & 20.6 & 140 & 353.7 \\
& 2014 & 3899.7 & 85.5 & 30 & 3853.6 & 661.1 & 14.5 & 66 & 115.5 \\
\hline
\end{tabular}

Area $(C F A=100 \cdot C F / T A)$;

- Changes in Non-forest Area in relation to Total Area $(C N A=100 \cdot C N / T A)$;

- Changes in Forest Area in relation to Forest Area in $1848\left(C F T_{1848}=C A-F A_{1848}\right)$;

- Changes in Non-forest Area in relation to Non-forest Area in $1848\left(C N T_{1848}=C A-\right.$ $\left.N A_{1848}\right)$;

- Percentage changes in Forest Area between time section $t+1$ and $t[C P F=100$. $\left.\left(F A_{\mathrm{t}}+1-F A_{\mathrm{t}}\right) / F A_{\mathrm{t}}\right]$;

- Percentage changes in Non-forest Area between time section $t+1$ and $t[C P N=$ $\left.100 \cdot\left(N A_{\mathrm{t}}+1-N A_{\mathrm{t}}\right) / N A_{\mathrm{t}}\right]$.

\section{Analysis of vegetation changes}

The analysis of changes in forest and nonforest areas was conducted for the years 1848-2014 on the basis of the available cartographic resources (Tab. 1). The maps differed with regard to land-cover forms (including vegetation types). Only some maps contained information on forest types, which were classified as deciduous or coniferous. Consequently, it was not possible to compare vegetation changes (in terms of plant communities and associations) for all time intervals. Therefore, vegetation changes over time were inferred by comparing the current vegetation map based on field mapping performed with an itinerary method (Sadikov 2012) and the map of potential natural vegetation of Poland (Matuszkiewicz et al. 1995). The latter map was used as reference for determining changes in the forest associations in the analysed areas. It was the only applicable method due to lack of information on past forest types in the study area.

\section{Results}

Changes in forest and non-forest cover in years 1848-2014

In both study areas, the forest cover grew systematically at the expense of nonforest areas in the period 1848-2014 due to the abandonment of agriculture (Tab. 2, Tab. 3, Fig. 2, Fig. 3). The increase in forest cover in the Racza Range was higher than
Tab. 3 - Dynamics of land cover changes between 1848 and 2014. (CF): Changes of Forest Area; $(C F A)$ : Changes of Forest Area relative to Total Area; $(C F T)$ : Changes of Forest Area relative to Forest Area in 1848; $(C P F)$ : Percentage changes of Forest Area between time section $t+1$ and $t ;(C N)$ : Changes of Non-forest Area; $(C A N)$ : Changes of Non-forest Area in relations to Total Area; $(C N T)$ : Changes of Non-forest Area in relations to Non-forest Area in 1848; $(C P N)$ : Percentage changes of Non-forest Area between time section $t+1$ and $t$.

\begin{tabular}{|c|c|c|c|c|c|c|c|c|c|}
\hline Range & $\begin{array}{l}\text { Time } \\
\text { interval }\end{array}$ & $\begin{array}{l}C F \\
\text { (ha) }\end{array}$ & $\begin{array}{c}C F A \\
\text { (\%) }\end{array}$ & $\begin{array}{c}C F T \\
\text { (ha) }\end{array}$ & $\begin{array}{c}C P F \\
\text { (ha) }\end{array}$ & $\begin{array}{l}C N \\
\text { (ha) }\end{array}$ & $\begin{array}{c}C N A \\
\text { (\%) }\end{array}$ & $\begin{array}{c}C N T \\
\text { (ha) }\end{array}$ & $\begin{array}{c}C P N \\
\text { (ha) }\end{array}$ \\
\hline \multirow{5}{*}{$\begin{array}{l}\text { Barania } \\
\text { Góra }\end{array}$} & $1848-1879$ & 8.4 & 0.2 & 8.4 & 0.2 & -8.4 & -0.2 & -8.4 & -1.0 \\
\hline & $1879-1933$ & 133.6 & 3.0 & 142.0 & 3.6 & -133.6 & -3.0 & -142.0 & -16.7 \\
\hline & $1933-1960$ & 304.5 & 6.8 & 446.2 & 7.9 & -304.5 & -6.8 & -446.2 & -45.8 \\
\hline & $1960-1979$ & 68.6 & 1.5 & 514.8 & 1.7 & -68.6 & -1.5 & -514.8 & -19.0 \\
\hline & $1979-2014$ & 16.3 & 0.4 & 531.1 & 0.4 & -16.3 & -0.4 & -63.8 & -5.6 \\
\hline \multirow[t]{5}{*}{ Racza } & 1848-1885 & 26.2 & 0.6 & 26.2 & 0.8 & -26.2 & -0.6 & -26.2 & -1.8 \\
\hline & $1885-1933$ & 98.5 & 2.2 & 124.7 & 3.1 & -98.5 & -2.2 & -124.7 & -7.1 \\
\hline & 1933-1975 & 329.7 & 7.2 & 454.4 & 10.1 & -329.7 & -7.2 & -454.4 & -25.4 \\
\hline & 1975-1979 & 27.2 & 0.6 & 481.6 & 0.8 & -27.2 & -0.6 & -481.6 & -2.8 \\
\hline & $1979-2014$ & 280.3 & 6.1 & 761.9 & 7.7 & -280.3 & -6.1 & -761.9 & -29.83 \\
\hline
\end{tabular}



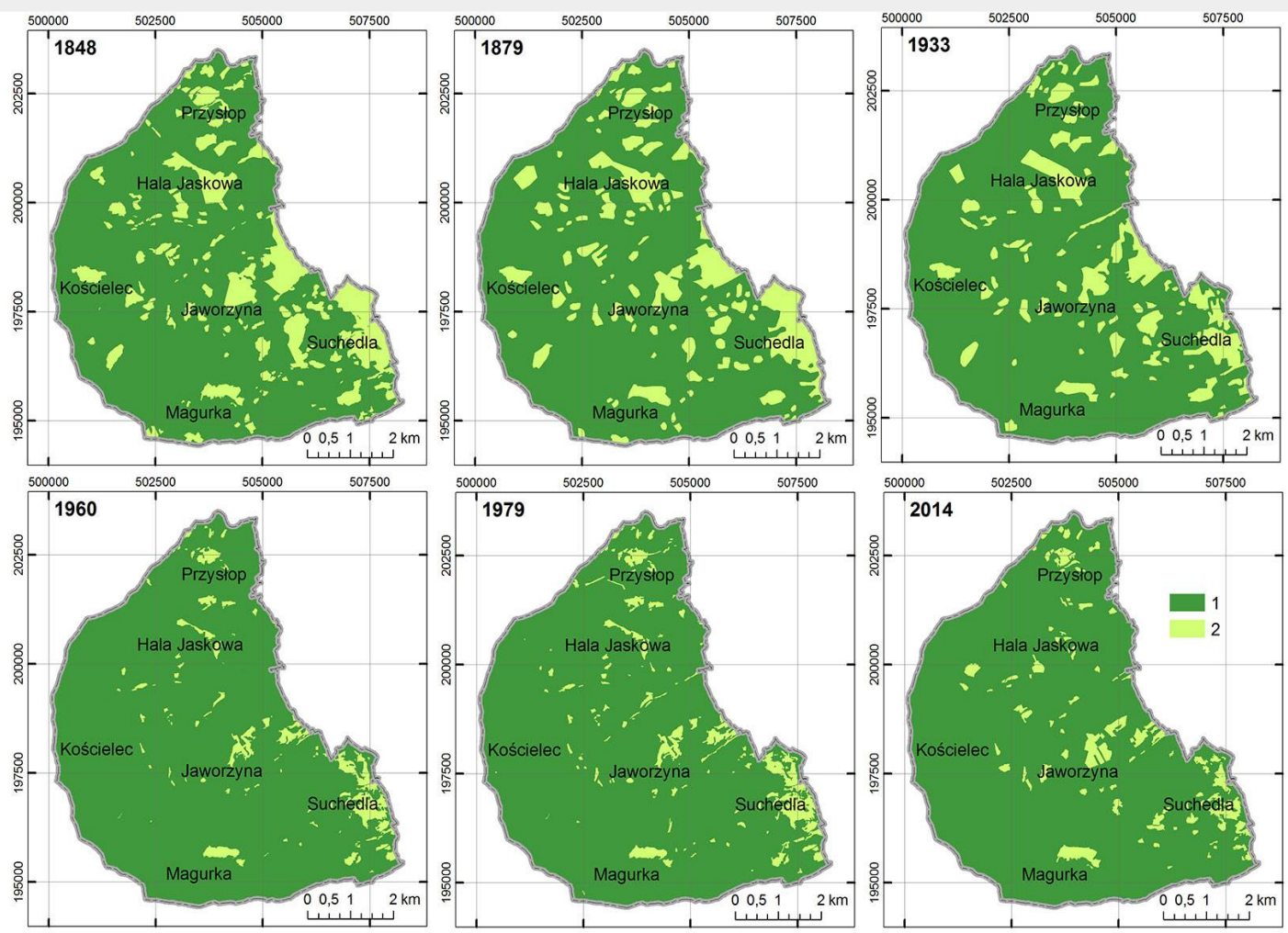

Fig. 2 - Changes in forest land cover in the Barania Góra Range between 1848 and 2014. (1): Forest areas (dark green); (2): non-forest areas (light green).
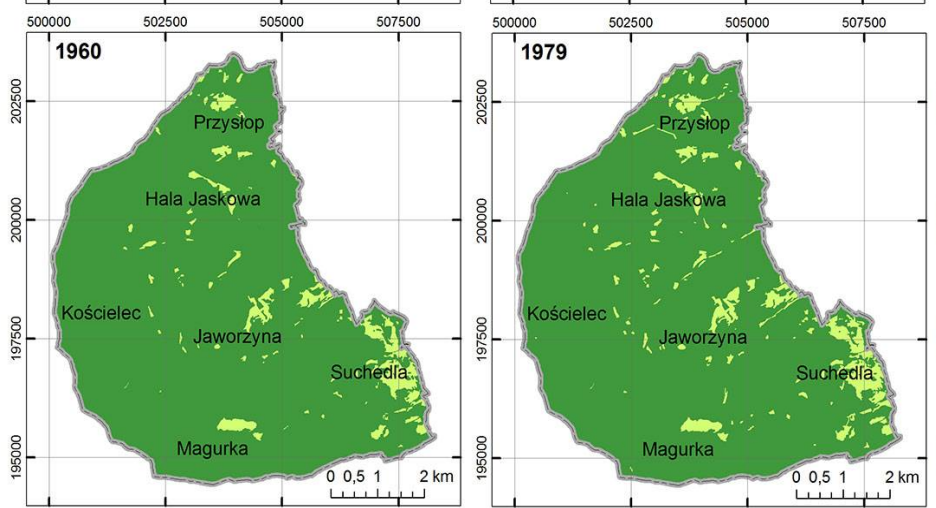

that observed in the Barania Góra Range forest patches, with different trends ( $16.7 \%$ vs. $11.8 \%$, respectively). The greatest through time in the two studied regions. In changes in the Barania Góra Range, affect- the Barania Góra Range, we observed an ing $6.8 \%$ of the examined region, took increase in the largest forest patches over place between 1933 and 1960, whereas in the considered period, whereas in the Racthe Racza Range forest cover changed con- za Range it decreased until 1933 and then tinuously since 1933 and involve $13.9 \%$ of started to increase. the investigated area.

Throughout 1848-2014, the number of Changes in the forest-field boundary non-forest patches was higher than that of In both the Barania Góra Range and the
Racza Range, the length of the forest-field boundary initially decreased (by $39.4 \mathrm{~km}$ and $45.4 \mathrm{~km}$, respectively), and then increased (by 13.3 and $67.3 \mathrm{~km}$ ) before decreasing again (by 15.4 and $68.2 \mathrm{~km}$ ). The numbers of boundaries and patches reveal a similar tendency. In both study areas the forest-field boundary was observed to progressively decrease in elevation (Fig. 4). To illustrate the effect of the map scales on
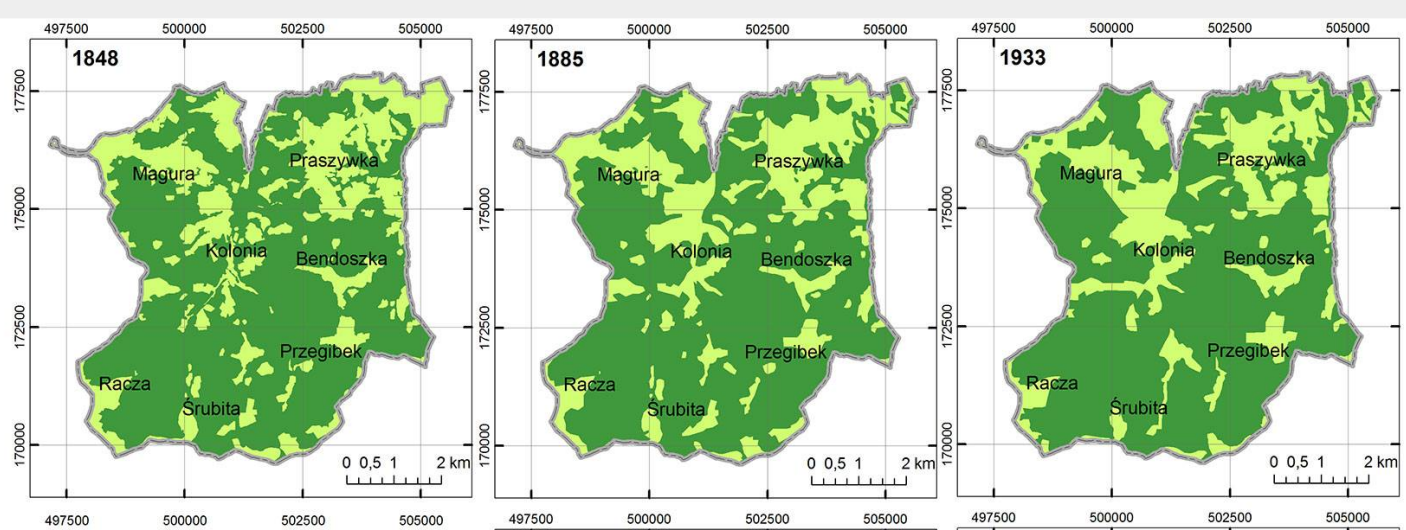

Fig. 3 - Changes in forest land cover in the Racza Range between 1848 and 2014. (1): Forest areas (dark green); (2): non-forest areas (light green).
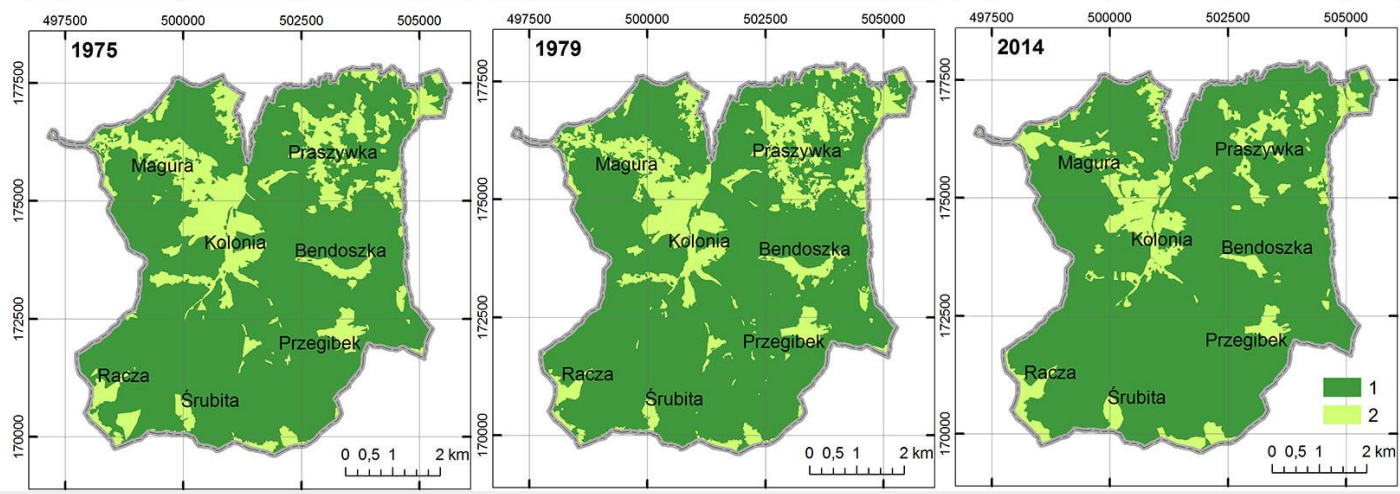


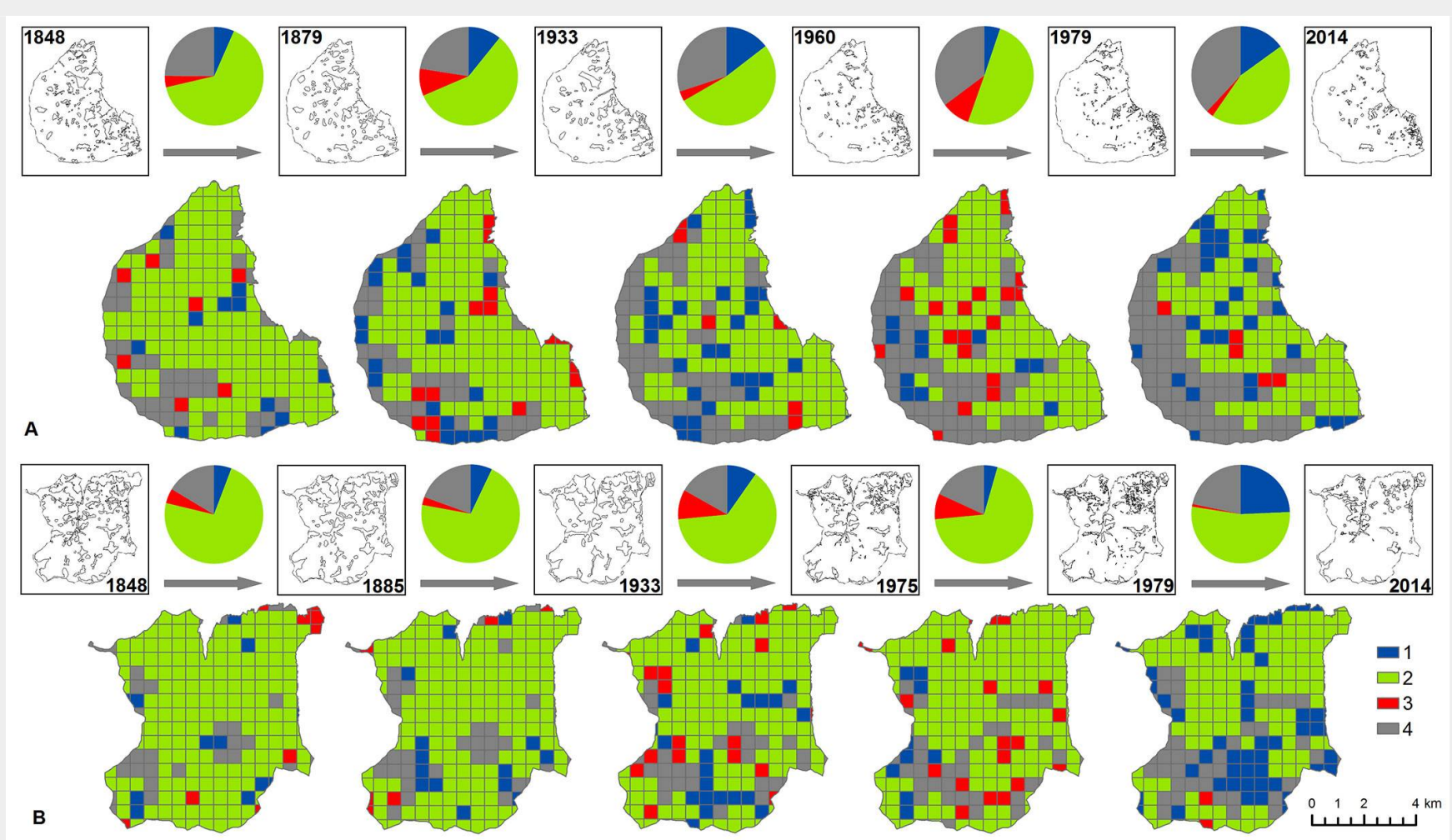

Fig. 4 - Dynamics of forest-field boundary occurrence in the Barania Góra Range (A) and Racza Range (B) between 1848 and 2014. The diagrams show the number of basic fields as follows: (1): vanished forest-field boundary (in blue); (2): continuing forest-field boundary (in green); (3): emerging forest-field boundary (in red); (4): no forest-field boundary (in grey).

the results, data on the number of borders and their minimum lengths are given in Tab. 4. The main trends of changes in the length and numbers of forest boundaries and patches are shown in Tab. 5 .

\section{Vegetation changes}

The study area is situated within the foothills and the lower forest zone (lower subalpine zone) which is the optimum (climax) for Fagus sylvatica and Abies alba, the main species characterizing beech and firbeech forests. The plant communities typical of these layers are: Alnetum incanae, Carici remotae-Fraxinetum, Dentario glandulosae-Fagetum, Luzulo nemorosae-Fagetum, Sorbo-Aceretum carpaticum, Abieti-Piceetum montanum and Plagiothecio-Piceetum tatricum.

The comparison of potential natural vegetation with current vegetation distribution revealed large changes in both species composition and the distribution of forest associations in the two study area (Fig. 5).

The grey alder association Alnetum incanae can only be found at sites in alluvial river valleys on mountain alluvial soils. The main tree species is Alnus incana; other species are Fraxinus excelsior, Acer pseudoplatanus, Picea abies, Abies alba, Salix fragilis and Salix alba. Small areas in river valleys are occupied by ash carrs Carici remotae-Fraxinetum, where the tree layer is mainly represented by Fraxinus excelsior and Alnus glutinosa with the addition of $\mathrm{Fa}$ gus sylvatica, Acer pseudoplatanus, Picea excelsa, Alnus incana, Quercus robur, Salix alba and Salix fragilis. most extended floral habitat in the served parts of this association remained in Silesian and Zywiec Beskids is the fertile the Racza Range. The dominant associaCarpathian beech wood Dentario glandu- tion Dentario glandulosae-Fagetum typicum

Tab. 4 - Changes in the forest-field boundary between 1848 and 2014.

\begin{tabular}{lccccc}
\hline Study area & $\begin{array}{c}\text { Time } \\
\text { section }\end{array}$ & $\begin{array}{c}\text { Total Edge } \\
(\mathrm{TE}, \mathbf{k m})\end{array}$ & $\begin{array}{c}\text { Edge Density } \\
\left(\mathrm{ED}, \mathbf{~} \mathbf{~ h a}^{-1}\right)\end{array}$ & $\begin{array}{c}\text { Number of } \\
\text { Edge }(\mathrm{NE})\end{array}$ & $\begin{array}{c}\text { Minimal Edge } \\
(\mathrm{ME}, \mathrm{m})\end{array}$ \\
\hline Barania Góra & 1848 & 123.4 & 27 & 151 & 33 \\
Range & 1879 & 96.1 & 21 & 96 & 228 \\
& 1933 & 95.8 & 21 & 83 & 125 \\
& 1960 & 84.0 & 19 & 113 & 79 \\
& 1979 & 97.3 & 22 & 164 & 34 \\
Racza Range & 2014 & 81.9 & 18 & 123 & 48 \\
& 1848 & 156.7 & 34 & 106 & 45 \\
& 1885 & 120.5 & 26 & 62 & 188 \\
& 1933 & 111.3 & 24 & 47 & 280 \\
& 1975 & 151.3 & 33 & 134 & 81 \\
& 1979 & 178.6 & 39 & 222 & 33 \\
& 2014 & 110.4 & 24 & 96 & 62 \\
\hline
\end{tabular}

Tab. 5 - Trend of changes in boundary length and number of boundary and patches between 1848 and 2014. (+): increase; (-): decrease.

\begin{tabular}{lcccccc}
\hline \multirow{2}{*}{$\begin{array}{l}\text { Time } \\
\text { interval }\end{array}$} & \multicolumn{3}{l}{ Barania Góra Range } & \multicolumn{5}{c}{ Racza Range } \\
\cline { 2 - 7 } & $\begin{array}{c}\text { Boundary } \\
\text { length }\end{array}$ & $\begin{array}{c}\text { Boundary } \\
\text { number }\end{array}$ & $\begin{array}{c}\text { Patch } \\
\text { number }\end{array}$ & $\begin{array}{c}\text { Boundary } \\
\text { length }\end{array}$ & $\begin{array}{c}\text { Boundary } \\
\text { number }\end{array}$ & $\begin{array}{c}\text { Patch } \\
\text { number }\end{array}$ \\
\hline $1848-1879$ & - & - & - & - & - & - \\
$1879-1933$ & - & - & - & - & - & - \\
$1933-1960$ & - & + & + & + & + & + \\
$1960-1979$ & + & + & + & + & + & + \\
$1979-2014$ & - & - & - & - & - & - \\
\hline
\end{tabular}




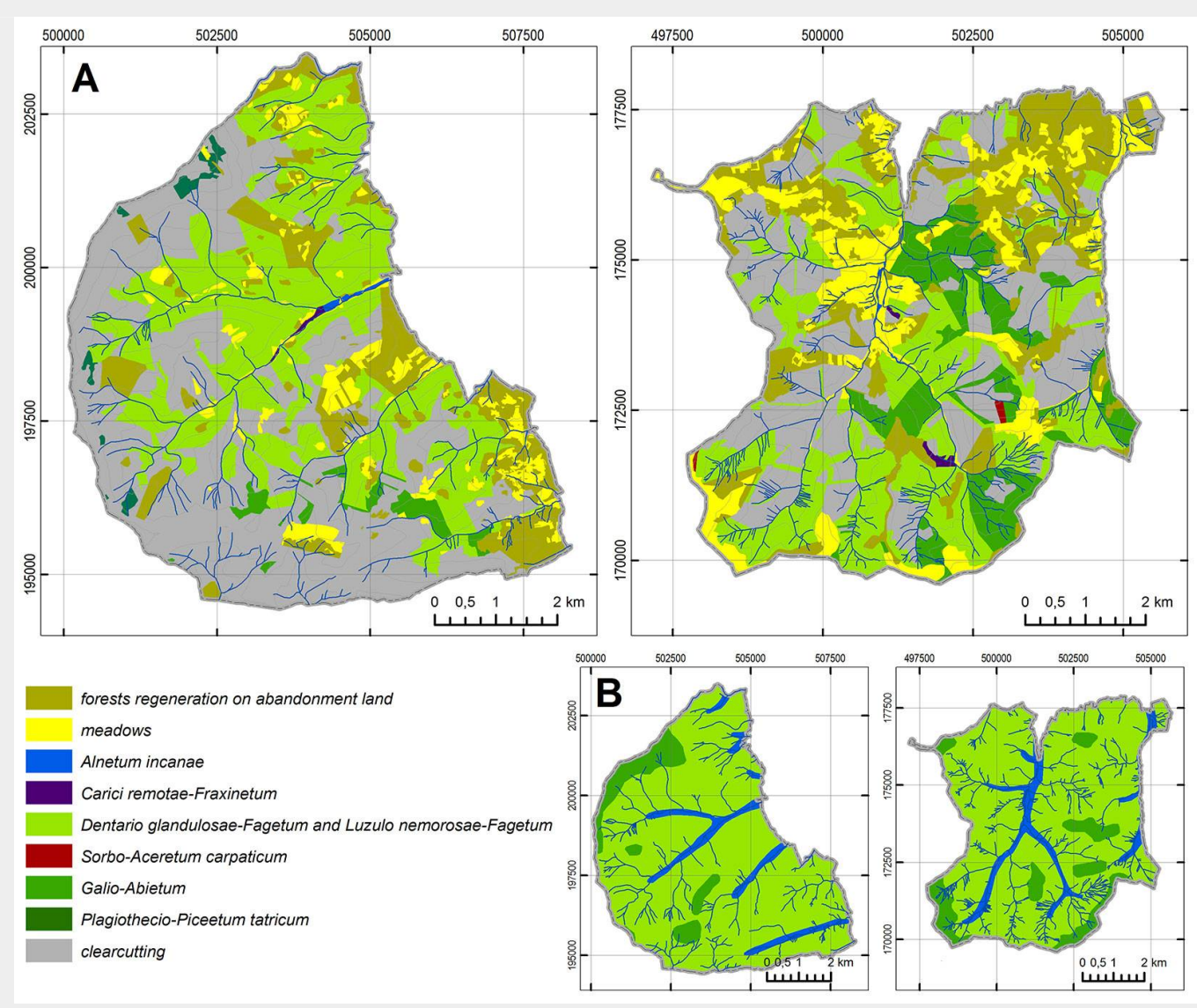

Fig. 5 - Changes in forest associations. (A): maps of curent forest associations in the two study areas (left panel: Barania Góra Range; right panel: Racza Range Sadikov 2012); (B): maps of potential natural vegetation (left panel: Barania Góra Range; right panel: Racza Range - from Matuszkiewicz et al. 1995). is composed of Fagus sylvatica, Acer psudoplatanus, Fraxinus excelsior, Abies alba and Picea abies. Another frequently occurring association is acid beech wood Luzulo nemorosae-Fagetum, which is almost solely composed of Fagus sylvatica, with a small proportion of Abies alba, Acer pseudoplatanus, Fraxinus excelsior, Picea abies, Betula pendula and Quercus robur.

The Carpathian sycamore Sorbo-Aceretum carpaticum, composed of Sorbus aucuparia, Acer pseudoplatanus, and Fagus sylvatica with a proportion of Picea abies, occurs sporadically, with trees often low and twisted.

Near-top parts of slopes are mainly occupied by the low montane fir-spruce wood Abieti-Piceetum montanum. The tree layer is composed of Picea abies, Abies alba, Fagus sylvatica, Sorbus aucuparia; Acer pseudoplatanus and Betula pendula also occur sporadically.

The West-Carpathian spruce forest association Plagiothecio-Piceetum tatricum is not commonly found due to the altitude of the study area. Small fragments can be found in higher parts of the Barania Góra Range. The dominant species is Picea abies with a rare amount of Sorbus aucuparia.

Non-forest patches with dominant seminatural associations often occur within the forests in the two study areas. These patches mainly include various types of meadows and pastures, characterized by the following plant communities: GladioloAgrostietum, Hieracio-Nardetum, Arrhenatheretum medioeuropaeum, Cirsietum rivu- laris and Juncetum effusi. Some of the lower meadows transformed into permanent hamlets. Starting from mid-19 ${ }^{\text {th }}$ century, recolonization by forest tree species decreased the size of non-forest patches (Fig. 2, Fig. 3, Tab. 2, Tab. 3). Currently, large areas without forest cover are present in higher parts of the hills and on hilltops, due to planned forest management in the early $21^{\text {st }}$ century (Fig. 5).

\section{Discussion}

Map types and interpretation of results The maps used in this study differ both in terms of scale (from 1:2,880 of the Austrian cadastral maps to $1: 100,000$ of the WIG military maps), their use (military or administrative purposes) and map projection. Therefore, results based on these maps need careful interpretation and verification using other data sources. Furthermore, the results could be affected by errors occurring at each stage of the creation of a digital map; particularly, georeferencing greatly affects the quality of results. Furthermore, the information value of map data is lower compared to direct source data, having a lower precision and accuracy. Being aware of the limitations of maps is the basis for drawing correct conclusions (Plit 2006).

The main results of this study, obtained by applying the most appropriate methods of analysis of cartographic historical data, can be summarized as follows:

- The dynamics of changes in land cover in two areas of the Beskid mountains were assessed by comparing the distribution and extension of different land cover types on maps from different time intervals. Although the results obtained should not be treated as absolute (see the above considerations), it was still possible to assess the trends related to changes in land cover in the study areas.

- The course of the forest-field boundary was analyzed with great care, as its length and density are particularly dependent on the map scale. The geometric simple choropleth method was used for this purpose. Applying a definite size of the basic field in relation to some generalization of the map contents allows excessive precision to be avoided. The size of the basic field was determined by the geometric method.

- The detection of changes in forest ecosystems based on cartographic materials was feasible only in terms of tracking changes in spatial distribution of forest/ non-forest areas. A detailed analysis of changes in forest ecosystems in terms of transformations of particular forest associations (their spatial distribution and composition in species) is only possible based on field research. The comparison of current distribution of particular forest associations with the potential vegetation has provided important hints for assessing the impact of cultural-historical factors on changes in forest ecosystems. 
Changes in land use between 1848-2014 Forest landscapes in the Silesian- and Zywiec Beskids are located at higher elevations (forest belt) and include non-forest glades and pastures. On the other hand, agricultural landscapes are situated at lower elevations (foothill belt), and includes forest patches, like small enclaves next to water courses or on steeper slopes. Our results highlight that the forest belt increased in the period 1848-2014 at the expense of the foothill belt. As in other parts of the Carpathians, changes in the forest area were closely related to changes in the range of areas used for agricultural activities (Farina 2000, Munteanu et al. 2014, Boltiziar et al. 2016).

Our results on the length of the forestfield boundary should not be treated as actual absolute values. However, they can be useful to assess the importance of the various spatial processes involved in the transformation of the landscape (Forman 1995). In general, we observed a decrease in length of the forest-field boundary through time, and a reduction in number of boundaries and patches. This could have been caused by the shrinkage of non-forest patches rather than their fragmentation. When fragmentation of patches becomes dominant over their shrinkage, the number and length of boundaries and the number of patches started to increase (Forman 1995).

The trends in land use in the two studied areas were mainly determined by non-environmental factors. Land use in 1848 was the result of the so-called "land hunger". Overpopulation and poor economic conditions forced to set arable lands at higher elevations and sloping hills, although most sites were unsuitable for crops. As a result, land use was far from sustainable in the mid- $19^{\text {th }}$ century and the pressure on the environment was high. At that time, the landscape was highly diversified, as occurring in other European countries (Antrop 2005).

Due to slightly different starting natural conditions, the land use structure was closer to the optimum in the Racza Range than in the Barania Góra Range, being the latter lesser managed than the former. This reflects the harsher geomorphological conformation of the Racza Range, which still represents a barrier for transports (Sobala 2012b).

Starting from the late $19^{\text {th }}$ century, intensified forest management and access limitations to forests contributed to a progressive reduction of the traditional meadowpasture management. Furthermore, increased acquisition of land for residential building and crops caused a reduction in the area for pasture. Additionally, the outflow of people towards the growing industrial centers and high market competition for sheep products contributed to the abandonment of pasture management in the higher parts of the mountains (Gerard et al. 2006, Kuemmerle et al. 2007). As a consequence, clearings and pastures were overgrown with forest and their size decreased. Nevertheless, grazing continued in some clearings and pastures until the 1990s. The gradual disappearance of seasonal shepherding resulted in secondary succession of forest to take place onto unused pastures and clearings; some of these are now completely forested (Fig. 6a).

The decrease in the non-forest area is still ongoing on the entire range of the Polish Carpathians as a result of political changes and socio-economic transformation, e.g., the ending of subsidies for mountain farms, the 1988 act on business activities which fostered non-agricultural activities, the decrease in demand for sheep products, increased production costs and the lower profitability of farming (Müller et al. 2013, Griffiths et al. 2014). In some cases, owners intentionally planted trees on some parts of unused clearings. Since the early $20^{\text {th }}$ century, programs of active nature protection using sheep grazing have been implemented in selected clearings and pastures, thus contributing to slow down secondary forest succession (Fig. 6b - Sobala 2014). Such actions have been successfully implemented in many other mountain regions of Europe (Finck et al. 2002). After Poland's accession to the European Union, a new agricultural policy and an increased awareness of the loss of valuable plant communities in mountain areas led to more appropriate management of those regions.

\section{Forest clearings and biodiversity}

Changes in land cover in the Barania Góra and Racza Ranges since 1848 have contributed to renaturalization of formerly cultivated forest clearings through the recolonization of forest tree species. On the other hand, the ecological consequences of such changes involve a decrease in biodiversity, a larger fragmentation of rare habitats, the weakening of soil denudation and microclimatic changes (Ostafin 2009, Munteanu et al. 2014), as well as a decreased scenic value (Plit \& Myga-Piatek 2014, Plit \& Myga-Piatek 2016) due to the homogeneization of the landscape (Farina 2000, Déjeant-Pons 2006).

The recolonization by forest tree species of abandoned pastures and meadows poses a serious threat to such communities in terms of species and ecosystem biodiversity (Towpasz \& Zemanek 1995), including a very large group of rare and unique mountain species protected by law, not only in Poland. Plant communities found in the studied area are relevant at the European context and would deserve protection as Natura 2000 areas. Such communities include Hieracio-Nardetum, Carlino-Dianthetum, Cirsietum rivularis, Adenostylion alliariae, Arrhenatheretum elatioris and Gladiolo-Argostietum caninae.

Our results indicate that plant communities in the study areas have been significantly transformed by man and do not re-

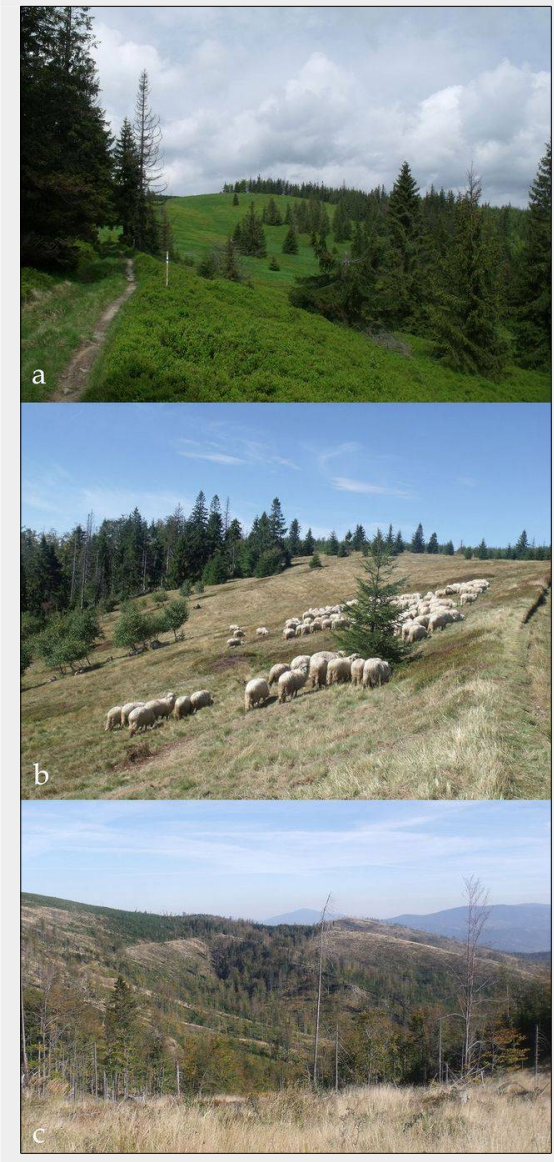

Fig. 6 - (a) Secondary succession of forest onto unused pastures; (b) Sheep grazing as a nature conservation measure; (c) Clearcutting as a result of forest degradation.

flect the potential natural vegetation at present. Starting from the late $15^{\text {th }}$ century, forests were thinned (by burning or cutting down) in order to obtain land for grazing and agriculture (Sobala 2016). As a result, the range of Alnetum incanae and Carici remotae-Fraxinetum decreased in river valleys. Moreover, the field-forest boundary moved upwards, shrinking the range of Dentario glandulosae-Fagetum and Luzulo nemorosae-Fagetum, which were replaced by ploughland at lower locations and by meadows and pastures at higher altitudes.

The history of vegetation in the Beskids can only be revealed indirectly based on paleobotanical research. The dominance of Fagus sylvatica, Abies alba, Alnus incana, Fraxinus excelsior and Picea abies is confirmed by paleobotanical studies conducted in numerous locations in the Polish Carpathians (Towpasz \& Zemanek 1995, Wilczek 1995). Forests in Silesian and Zywiec Beskids probably share a common history with other Carpathian forests. Beech and fir colonized the current forest areas of the Beskids after the spruce, which was the dominant species until ca. $2000 \mathrm{BC}$, and by $300 \mathrm{AD}$ they occupied the largest habitat area. Until the $15^{\text {th }}$ century the Beskids were covered by natural mixed (mainly fir- 
beech) forests, with increasing proportion of spruce with altitude (Wilczek 1995). Only small patches, such as steep slopes and narrow belts on river bank gravels, were not covered by forest. Following the introduction of grazing in the late $15^{\text {th }}$ century pastures were created within the AbietiPiceetum montanum, and forests surrounding villages were used for tree logging and branch litter collection. However, it was in the $19^{\text {th }}$ century, when forest management was introduced, that large transformations of forests took place (Broda 1956, Vera 2000, Plit 2014). Mass forest thinning for industrial needs changed the spatial distribution of forest communities and their species composition. As a result, lower subalpine beech-fir tree stands were destroyed and replaced with spruce plantations (Sobala 2012C), whereas the area of AbietiPiceetum montanum increased at higher altitudes. Most patches of this plant community are of secondary origin and have poor species composition, e.g., the share of Abies alba is much lower in the study area compared to patches in other parts of the Carpathians (Wilczek 1995). At the beginning of the $21^{\text {st }}$ century, forests in large areas were degraded to such an extent (because of biotic, abiotic and anthropogenic factors) that tree clearance appeared to be necessary (Fig. 6c - Malek et al. 2010). At present, these regions are undergoing the regeneration of forest community, according to their habitats (Farina 2000, DéjeantPons 2006, Hlasny \& Sitkova 2010).

Changes in land use due to deforestation and subsequent reforestation are common to many mountain regions, especially in developed countries, and are called "forest transition" (Mather 1992, Rudel et al. 2005, Meyfroidt \& Lambin 2011). Reforestation started in Western Europe in the early $19^{\text {th }}$ century and developed after World War II (Mayher 2001). In Central and Eastern Europe, the increase in forest areas was mainly related to socio-economic transformations in the countries of the former Eastern Bloc in the late 1990s (Gellrich et al. 2007, Bičík \& Jeleček 2009, Griffiths et al. 2013). However, in the Western Beskids deforestation took place later due to the shortage of land resources, and reforestation started in the late $19^{\text {th }}$ century, when forest management intensified and less suitable arable lands were abandoned (Verburg et al. 2010, Munteanu et al. 2014).

\section{Conclusions}

This study identified the following effects of land use and landscape changes in the past 200 years:

- The forested area in the Racza and Barania Góra Ranges grew systematically between 1848-2014 at the expense of nonforest areas, where farming was abandoned. The number of non-forest patches was higher than that of forest patches. Changes in the forest areas in this part of the Carpathians have continued since the early $20^{\text {th }}$ century.
- The area of clearings and pastures decreased significantly because of intensified forest management, the use of land for residential buildings and crops, and the natural recolonization by forest tree species. All these factors contributed to the gradual decline of traditional meadow-pasture management.

- Changes in the forest/non-forest cover over time were accompanied by a decrease/increase in the length of the forest-field boundary and its lowering relative to altitude. The attrition of the boundary progressed from the highest levels of the mountains to areas close to permanent rural buildings.

- Analysis of cartographic resources and historical scientific papers, along with field verification, enabled a full interpretation of changes in land use in the chosen time interval. The study of historical maps combined with contemporary field data has potential for monitoring further landscape dynamics.

The approach applied in this study could be easily extended to other Carpathian regions subject to analogous historical-cultural influences (similar type of settlement, model of land use, policy regarding agriculture and environment, etc.). Moreover, the results obtained allow the comparison with other regions in Europe subject to a similar impact of natural processes, but a different impact of historical and cultural processes.

\section{Acknowledgements}

We gratefully acknowledge two anonymous reviewers for their constructive comments.

\section{References}

Affek A (2013). Georeferencing of historical maps using GIS as exemplified by the Austrian Military Surveys of Galicia. Geographia Polonica 86 (4): 375-390. - doi: 10.7163/GPol.2013.30

Antrop M (2005). Why landscapes of the past are important for the future. Landscape and Urban Planning 70: 21-34. - doi: 10.1016/j.land urbplan.2003.10.002

Bičík I, Jeleček L (2009). Land use and landscape changes in Czechia during the period of transition 1990-2007. Geografie - Sborník CGS 114 (4): 263-281.

Boltiziar I, Olah B, Gallay I, Gallayova Z (2016). Transformation of the Slovak cultural landscape and its recent trends. In: Proceedings of the " $17^{\text {th }}$ International Symposium on Landscape and Landscape Ecology" (Hlada L, Baca A, Boltiziar M eds). Nitra (Slovakia) 27-29 May 2015, pp. 57-67.

Broda J (1956). Gospodarka lesna w dobrach zywieckich do konca XVIII w [Forest management in the area of Zywiec until the end of the 18th century]. PWN, Warszawa, Poland, pp. 200. [in Polish]

Déjeant-Pons M (2006). Head of the spatial planning and landscape division. The European Landscape Convention. Landscape Research 31 (4): 363-384. - doi: 10.1080/01426390601004343 Ellis EC (2015). Ecology in an anthropogenic biosphere. Ecological Monographs 85 (3): 287-331. doi: $10.1890 / 14-2274.1$

Farina A (2000). The cultural landscape as a model for the integration of ecology and economics. BioScience 50: 313-320. - doi: 10.1641/00 06-3568(2000)050[0313:TCLAAM]2.3.CO;2

Finck U, Riecken U, Schroder E (2002). Pasture landscapes and nature conservation - New strategies for preservation of open landscapes in Europe. In: "Pasture Landscape and Nature Conservation" (Redecker B, Finck P, Hardtle W, Riecken U, Schroder E eds). Springer Science \& Business Media, University of Lüneburg, Luneburg, Germany, pp. 1-14. [online] URL: http:// books.google.com/books?id=WZzqpUk5zFkC

Forman RTT (1995). Land mosaics. The ecology of landscapes and regions. Cambridge University Press, Cambridge, UK, pp. 632.

Gellrich M, Baur P, Koch B, Zimmermann NE (2007). Agricultural land abandonment and natural forest re-growth in the Swiss mountains: a spatially explicit economic analysis. Agriculture, Ecosystems and Environment 118: 93-108. - doi: 10.1016/j.agee.2006.05.001

Gerard F, Thomson A, Wadsworth R, Gregor M, Luque S, Sandra L, Huitu H, Köhler R, Olschofsky K, Hazeu G, Mucher S, Halada L, Bugár G, Pino J (2006). Land cover change in Europe from the 1950 s to 2000 . Aerial photo interpretation and derived statistics from 59 samples distributed across Europe. Institute for World Forestry. University of Hamburg, Hamburg, Germany, pp. 364.

Goldewijk KK (2001). Estimating global land use change over the past 300 years: the HYDE Database. Global Biogeochemical Cycles 15 (2): 417-433. - doi: 10.1029/1999GB001232

Griffiths $\mathrm{P}$, Müller M, Kuemmerle T, Hostert P (2013). Agricultural land change in the Carpathian ecoregion after the breakdown of socialism and expansion of the European Union. Environmental Research Letters 8 (4): 1-12. doi: 10.1088/1748-9326/8/4/045024

Griffiths P, Kuemmerle T, Baumann M, Radeloff VC, Abrudan IV, Lieskovsky J, Munteanu C, Ostapowicz K, Hostert P (2014). Forest disturbances, forest recovery, and changes in forest types across the Carpathian ecoregion from 1985 to 2010 based on Landsat image composites. Remote Sensing of Environment 151: 7288. - doi: 10.1016/j.rse.2013.04.022

Hansen MC, Stehman SV, Potapov PV (2010). Quantification of global gross forest cover loss. Proceedings of the National Academy of Science USA 107: 8650-8655. - doi: 10.1073/pnas. 0912668107

Hlasny T, Sitkova Z (2010). Spruce forest decline in the Beskids. Forest Research Institute Zvolen and Czech University of Life Sciences, Prague and Forestry and Game Management Research Institute Jílovište, Strnady, Czech Republic, pp. 184.

Kaim D (2009). Zmiany pokrycia terenu na pograniczu polsko-slowackim na przykladzie Malych Pienin [Land-cover changes in PolishSlovakian border regions: a case study of the Male Pieniny Mts]. Przeglad Geograficzny 81 (1): 93-105. [in Polish] - doi: 10.7163/PrzG.2009. 4.4 Kozak J (2003). Forest cover change in the Western Carpathians in the past 180 Years. Mountain Research and Development 23 (4): 369-375. 
doi: CITW]2.0.CO;2

Kozak J (2010). Forest cover changes and their drivers in the Polish Carpathian Mountains since 1800. In: "Reforesting Landscapes Linking Pattern and Process" (Nagendra H, Southworth J eds). Landscape Series 10, Springer, Dordrecht, Heidelberg, London, New York, pp. 253-273.

Kozak J, Estreguil C, Troll M (2007). Forest cover changes in the northern Carpathians in the 20th century: a slow transition. Journal of Land Use Science 2: 127-146. - doi: 10.1080/174742307 01218244

Kuemmerle T, Hostert P, Radeloff VC, Perzanowski K, Kruhlov I (2007). Post-Socialist forest disturbance in the Carpathian border region of Poland, Slovakia and Ukraine. Ecological Applications 17: 1279-1295. - doi: 10.1890/06-1661.1

Malek S, Barszcz J, Kedziora B (2010). Assessment of European beech in cultures located at higher altitudes of the Beskid Slaski and Zywiecki. Sylwan 154 (10): 710-720. [online] URL: http://www.cabdirect.org/cabdirect/abstract/2 0113027803

Maras SS, Maras HH, Aktug B, Maras EE, Yildiz F (2010). Typological error correction of GIS vector data. International Journal of the Physical Sciences 5 (5): 476-483.

Mather AS (1992). The forest transition. Area 24 (4): 367-379.

Matuszkiewicz W, Falinski JB, Kostrowicki AS, Matuszkiewicz JM, Olaczek R, Wojterski T (1995). Potencjalna roslinnosć naturalna Polski [Map of potential natural vegetation of Poland]. Mapa przegladowa 1:300,000, IGiPZ PAN, Warszawa, Poland. [in Polish]

Mayher AS (2001). The transition from deforestation to reforestation in Europe. In: "Agricultural Technology and Tropical Deforestation" (Angelsen A, Kaimowitz D eds). CABI, Wallingford, UK, pp. 35-52.

Meyfroidt P, Lambin E (2011). Global forest transition: prospects for an end to deforestation. Annual Review of Environment and Resources 36: 343-371. - doi: 10.1146/annurev-environ-0907 10-143732

Munteanu C, Kuemmerle T, Boltiziar M, Butsic V, Gimmig U, Halada L, Kaim D, Király G, KonkolyGyuró E, Kozak J, Lieskovsky J, Mojses M, Müller D, Ostafin K, Ostapowicz K, Shandra O, Walker S, Radeloff VC (2014). Forest and agricultural land change in the Carpathian region a meta-analysis of long-term patterns and drivers of change. Land Use Policy 38: 685-697. doi: 10.1016/j.landusepol.2014.01.012

Myga-Piatek U (2012). Krajobraz kulturowy. Aspekty ewolucyjne i typologiczne [Cultural landscapes. Evolutionary and typological aspects].
Uniwersytet Slaski, Katowice, Poland, pp. 376. [in Polish]

Müller D, Leitão PJ, Sikor T (2013). Comparing the determinants of cropland abandonment in Albania and Romania using boosted regression trees. Agricultural Systems 117: 66-77. - doi: 10.1016/j.agsy.2012.12.010

Ostafin K (2009). Zmiany granicy rolno-lesnej w srodkowej czesć Beskidu Sredniego od pol. XIX w. do $2005 \mathrm{r}$ [Changes in the forest-field boundary in the middle part of the Makowski Beskid from the mid-19 ${ }^{\text {th }}$ century to 2005]. Wydawnictwo Uniwersytetu Jagiellonskiego, Kraków, Poland, pp. 167. [in Polish]

Pienkowski $P$ (2015). Ocena fragmentacji lasów Pomorza Zachodniego pomiedzy XV a XX wiekiem [Evaluation of the forest fragmentation in Western Pomerania between the $15^{\text {th }}$ and $20^{\text {th }}$ century]. Sylwan 159 (7): 610-616.

Pinto-Correia T, Kristensen L (2013). Linking research to practice: the landscape as the basis for integrating social and ecological perspectives of the rural. Landscape Urban Planning 120: 248-256. - doi: 10.1016/j.landurbplan.2013.0 7.005

Plieninger T, Drauxa H, Fagerholma N, Bielingc C, Bürgi M, Kizos T, Kuemmerle T, Primdahl J, Verburg PH (2016). The driving forces of landscape change in Europe: a systematic review of the evidence. Land Use Policy 57: 204-214. - doi: 10.1016/j.landusepol.2016.04.040

Plit J, Myga-Piatek U (2014). The degree of landscape openness as a manifestation of cultural metamorphoses. Quaestiones Geographicae 33 (3): 145-154. - doi: 10.2478/quageo-2014-0036

Plit J, Myga-Piatek U (2016). Investigating openness of the cultural landscape - a methodological proposal. Geographica Polonica 89 (2): 129140. - doi: 10.7163/GPol.0050

Plit J (2006). Analiza historyczna jako zródlo informacji o srodowisku przyrodniczym [Historical analysis as a source of information on natural environment]. Problemy Ekologii Krajobrazu 16: 217-226. [in Polish]

Plit J (2014). Secular forest exploitation and its landscape consequences evolution of forest landscapes on Polish territories. Prace Komisji Krajobrazu Kulturowego 23: 149-164.

Rudel TK, Coomes OT, Moran E, Achard R, Angelsen A, Xu J, Lambin E (2005). Forest transitions: towards a global understanding of land use change. Global Environmental Change 15: 23-32. - doi: 10.1016/j.gloenvcha.2004.11.001

Sadikov C (2012). The juniperus forests of catchment of Iskander river (Tajikistan). Lambert Academic Publishing, Saarbrücken, Germany, pp. 1-150.

Sobala M (2012a). Zastosowanie austriackich map katastralnych w badaniach uzytkowania ziemi w polowie XIX wieku [Application of Austrian cadastral maps in research on land use in the middle of $19^{\text {th }}$ century]. Polski Przeglad Kartograficzny 44 (4): 324-333.

Sobala M (2012b). Rola materialów kartograficznych w wyznaczaniu granic obszaru badan zmian krajobrazu kulturowego [Carthographic materials and their importan part in delimitation borders of examined region of changes in cultural landscape]. Prace Komisji Krajobrazu Kulturowego 16: 105-115. [in Polish]

Sobala M (2012c). Rola tworzenia wielkoobszarowych zrebów zupelnych w zmianie struktury krajobrazu wschodniej czesci Beskidu Slaskiego [The role of great landed total in changes of landscape's structure of eastern part of Silesian Beskid]. Z badan nad wplywem antropopresji na srodowisko 13: 71-80. [in Polish]

Sobala M (2014). Krajobrazy pasterskie w Polsce i Europie. Wybrane typy, przyklady i formy ich ochrony [Pasture landscapes in Poland and Europe - selected types, examples and conservation methods]. Prace Komisji Krajobrazu Kulturowego 25: 81-98. [in Polish]

Sobala M (2016). Landscape effects of conflicts in space management. A historical approach based on the Silesian and Zywiec Beskids (West Carpathians, Poland). Environmental and Socioeconomic Studies 4 (4): 51-60. - doi: 10.1515/ environ-2016-0024

Towpasz K, Zemanek B (1995). Szata roslinna [Flora and Vegetation]. In: "Karpaty Polskie. Przyroda, czlowiek I jego dzialalnosć" [The Polish Carpathians: nature, man and its activity] (Warszynska J ed). Jagiellonian University Press, Kraków, Poland, pp. 77-94. [in Polish] Vera FWM (2000). Grazing ecology and forest history. CABI, Oxford, UK, pp. 506. [online] URL: http://www.cabdirect.org/cabdirect/abstr act/20003001196

Verburg PH, Berkel DB, Doorn AM, Eupen M, Heiligenberg HRM (2010). Trajectories of land use change in Europe: a model-based exploration of rural futures. Landscape Ecology 25: 217-232. - doi: 10.1007/s10980-009-9347-7

Vold T, Buffett DA (2008). Ecological concepts, principles and applications to conservation. Web site. [online] URL: http://www.biodiv ersitybc.org/

Wilczek Z (1995). Zespoly lesne Beskidu Slaskiego i zachodniej czesci Beskidu Zywieckiego na tle zbiorowisk lesnych Karpat Zachodnich [Forest's associations of the Silesian Beskid Mountains and western part of the Zywiecki Beskid Mountains on the background of the West Carpatians forest's communities] Wydawnictwo Uniwersytetu Slaskiego, Katowice, Poland, pp. 129. [in Polish] 